\title{
PEMIKIRAN EKONOMI ISLAM KONTEMPORER
}

\author{
Rizka Amaliah S
}

90100118102

Perkembangan ekonomi islam saat ini tidak dapat dipisahkan dari sejarah pemikiran muslim tentang ekonomi di masa lalu.keterlibatan pemikir muslimdalam kehidupan masyarakat yang kompleks dan belum adanya pemisahan disiplin keilmuwan menjadikan pemikir muslim melihat masalah masyarakat dalam konteks yang lebih integrative. (Mazhab, 2010)

Pada saat masyarakat dan bangsa Indonesia, khususnya kaum Muslim, mengalami krisis dalam berbagai bidang kehidupan, khususnya dalam bidang ekonomi, terdapat kesadaran transendental untuk mengembalikan persoalan ini pada ajaran Islam. Meskipun pada mulanya ajaran Islam dalam bidang ekonomi dianggap sebagai alternatif, akan tetapi secara bertahap dan mudah-mudahan meyakinkan, menjadi satusatunya pilihan dan keniscayaan. Hal ini setelah disadari bersama bahwa baik sistem kapitalis individualistis yang dibangun dan dikembangkan oleh blok Barat, maupun sistem komunis sosialis yang dibangun oleh blok Timur, ternyata tidak mampu menjawab berbagai persoalan ekonomi dan tidak mampu pula memberikan solusi bagi setiap persoalan kemanusiaan yang terjadi.(-, 2013). Kemudian ekonomi islam dianggap mempunyai potensi untuk mewujudkan keadilan dan kesejahteraan umum. Pemikiran ekonomi islam di bagi ke dalam dua masa, yaitu masa klasik dan masa modern (kontemporer). Pada artikel ini akan dibahas aliran ekonomi islam pada masa modern (kontemporer).

1. Aliran Iqtishaduna

Pola utama aliran ini adalah pemikiran tentang pemecahan masalah ekonomi yang muncul karena adanya distribusi yang tidak merata dan adil sebagai pengaruh dari ekonomi kapitalis yang menguntungkan pihak yang kuat dan kaya. Pemahaman ekonommi iqtishaduna berpendapat puncak 
permasalahan ekonomi adalah bukan karena sumber daya yang tidak terbatas, tetapi karena ketamakan manusia yang tidak terbatas. Aliran ini dipelopiri oleh Baqir Sadr.(Maulidizen Ahmad, 2017)

Pemikiran Baqir al-Sadr menyatakan Islam tidak mengurusi hukum permintaan dan penawaran, hubungan antara keuntungan dan bunga, juga fenomena diminishing return dalam produksi. Ekonomi Islam adalah doktrin karena ia membincangkan semua aturan dasar dalam kehidupan ekonomi dihubungkan dengan ideologi mengenai keadilan sosial. Menurut Sadr, masalah-masalah ekonomi lahir bukan disebabkan oleh kelangkaan sumbersumber material ataupun terbatasnya kekayaan alam. Hal ini didukung dengan dalil al-Quran Surat al-Qamar ayat 49 yang menyatakan "Sesungguhnya kami menciptakan segala sesuatu menurut ukurannya". Dari ayat tersebut yang kemudian diperkuat dalam al-Quran Surat Ibrahim ayat 32-34, Sadr berpendapat bahwa permasalahan ekonomi muncul kareana disebabkan oleh dua faktor yang mendasar. Pertama adalah karena prilaku manusia yang melakukan kezaliman, dan kedua karena mengingkari nikmat Allah SWT. Kambali

Madzhab Baqir juga berpendapat bahwa masalah ekonomi muncul karena adanya distribusi yang tidak merata dan adil sebagai akibat sistem ekonomi yang membolehkan eksploitasi pihak yang kuat terhadap pihak yang lemah. Yang kuat memiliki akses terhadap sumber daya sehngga menjadi sangat kaya, sementara yang lemah tidak memiliki akses terhadap sumber daya sehingga menjadi sangat miskin. Karena itu masalah ekonomi muncul bukan karena sumber manusia yang terbatas. Tetapi karena keserakahan manusia yang tidak terbatas.(-, 2013)

2. Aliran Mainstream

Pola utama dari pemikiran aliran ini adalah kebalikan dari aliran iqtisaduna. Perbedaannya adalah puncak permasalahan ekonomi, menurut mereka masalah ekonomi dikarenakan kekurangan (scarcity). Ini maksudnya 
segala sumber daya alam adalah terbatas tetapi keperluan manusia yang tidak terbatas. Untuk itu manusia diarahkan untuk melalukan aktivitas ekonomi berdasarkan kepada skala prioritas dalam memenuhi kebutuhan manusia dengan tetap berpegang teguh kepada al-Qur"an dan al-Hadith.(Maulidizen Ahmad, 2017)

Tokoh - tokoh utama pada aliran ini yaitu : M. Umer Chapra, Mannan, Nejatullah Siddiqi.

Pandangan mahzab ini tentang masalah ekonomi hampir tidak ada bedanya dengan pandangan ekonomi konvensional. Kelangkaan sumber dayalah yang menjadi penyebab munculnya masalah ekonomi. Perbedaan mazhab mainstream dengan ekonomi konvensional terletak pada cara menyelesaikan masalah tersebut. Perbedaannya terletak pada cara menyelesaikan masalah tersebut. Dalam Ekonomi konvensional pemilihan sekala prioritas berdasarkan selera masing-masing pribadi.Manusia boleh mempertimbangkan tuntutan agama atau boleh juga mengabaikannya. Tetapi dalam ekonomi islami pilihan tidak dapat dilakukan semaunya, harus berdasarkan tuntunan Alquran dan Assunah.(Arif, 2018)

\section{Aliran Alternatif Kritis}

Madzhab ini dipelopri oleh Timur Kuran, Jomo Dan Muhammad Arif. Madzhab ini mengkritik madzhab-madzhab sebelumnya. Madzhab Baqr dikritik sebagai madzhab yang ingin menemukan sesuatu yang sudah ada dan sudah ditemukan oleh orang lain, bahkan sudah diamalkan oleh orang lain. Menghancurkan teori yang lama dengan mengganti teori yang baru. Madzhab mainstream dikritik karena merupakan jiplakan dari konvensional yang menghilangkan riba kemudian mengganti dengan zakat dan niat. Sesuai namanya madzhab kritis maka nada kritis merupakan ciri khas madzhab ini. Menurutnya analisis kritis bukan saja terhadap sosialisme dan kapitaisme tetapi juga pada konsep ekonomi Islam.(Abidin, 2015) 


\section{DAFTAR PUSTAKA}

-, F. (2013). Paradigma Madzhab-Madzhab Ekonomi Islam Dalam Merespon Sistem Ekonomi Konvensional. AL-IHKAM: Jurnal Hukum \& Pranata Sosial, 7(1), 156-177. https://doi.org/10.19105/al-lhkam.v7i1.322

Abidin, Z. (2015). Mapping Pemikiran Akademisi dalam Madzhab Ekonomi Islam Kontemporer. IQTISHADIA: Jurnal Ekonomi \& Perbankan Syariah, 1(2), 263. https://doi.org/10.19105/iqtishadia.v1i2.484

Arif, M. (2018). Filsafat Ekonomi Islam. 1, 171.

Maulidizen Ahmad. (2017). Pemikiran Dan Kontribusi Tokoh Ekonomi Islam Klasik Dan Kontemporer. Jurnal DELIBERATIF; Jurnal Ilmiah Hukum, 1(1), 42-62.

Mazhab, P. D. A. N. (2010). Abstrak. 12, 15-26. 